\title{
Leishmaniose tegumentar americana: casuística hospitalar no Rio de Janeiro*
}

\section{American tegumentary leishmaniasis: hospitalized cases in Rio de Janeiro}

\author{
Nurimar C. Fernandes ${ }^{1}$ \\ Tullia Cuzzi
}

\author{
Isabela Morgan²
}

Juan P. Maceira

Resumo: Fundamentos - A leishmaniose tegumentar americana distribui-se amplamente no Brasil, e o Estado do Rio de Janeiro (capital e interior) constitui área endêmica onde o vetor é encontrado dentro e ao redor das habitações.

OBJEtivos - Análise prospectiva de 48 casos de leishmaniose tegumentar americana atendidos no Hospital Universitário Clementino Fraga Filho/UFRJ, no período de 1990 a 2002.

MÉTODOs - Todos os pacientes foram submetidos à biópsia de pele ou mucosa, teste de Montenegro e exame otorrinolaringológico; $\mathrm{Sb}^{\mathrm{v}}$ (10 a 20mg/kg), no total de 10, 30 e 90 doses. foi empregado em 44 pacientes; em quatro casos, anfotericina $B(0,5 \mathrm{mg} / \mathrm{kg} / \mathrm{dose})$ até dose cumulativa de $30 \mathrm{mg} / \mathrm{kg}$.

RESULTADOS - 28 homens e 20 mulheres na faixa etária de 10 a 89 anos, dos quais $38(79,1 \%)$ infectados no Rio de Janeiro, apresentaram úlcera de membro inferior e comprometimento de mucosa nasal como manifestações mais freqüentes; 41 casos (85,4\%) foram reatores à intradermorreação de Montenegro ( $\geq 5 \mathrm{~mm}) ; 17$ casos (35,4\%) foram positivos para o achado de amastigotas em macrófagos no infiltrado inflamatório dérmico; predominou o processo inflamatório crônico granulomatoso; cura clínica foi observada em 47 casos; um caso evoluiu para óbito no décimo dia de tratamento.

CONCLUSÕES - 0 estudo da leishmaniose tegumentar (HUCFF/UFRJ) no período 1990/2002 evidenciou padrão conhecido nos aspectos epidemiológicos, clínicos e de resposta terapêutica ao antimonial (Sb) e anfotericina $B$.

Palavras-chave: epidemiologia; leishmaniose; leishmaniose cutânea.

Summary: BACKGROUND: American tegumentary leishmaniasis is widely found in Brazil; the state of Rio de Janeiro (capital and hinterland) is an endemic area where the vector is found inside and outside houses. OBJECTIVES: prospective study of 48 cases attended at the Teaching Hospital Clementino Fraga Filho - UFRJ, between $1990-2002$.

METHODS: All patients were submitted to skin or mucosa biopsy, Montenegro skin test and otorhinolaryngologic examination; $\mathrm{Sb}^{\vee}(10-20 \mathrm{mg} / \mathrm{kg}$ ) with 10,30 and 90 doses was used in 44 patients; in 4 cases, Amphotericin B (0.5 mg/kg/dose) until cumulative dosage of $30-50 \mathrm{mg} / \mathrm{kg}$.

RESULTS: 28 males and 20 females aged 10 - 89 years mostly infected in Rio de Janeiro (38 cases/79.1\%) mainly presented ulcers in the extremities and involvement of nasal mucosa; 41 cases (85.4\%) were reactive to the Montenegro skin test ( $\geq 5 \mathrm{~mm}$ ); 17 cases (35.4\%) were positive for amastigotes in tissue sections; an inflammatory chronic granulomatous process was mostly seen. Clinical cure was observed in 47 cases; one patient died on day 10 of treatment.

CoNCLUSIONS: The study of American tegumentary leishmaniasis (HUCFF - UFRJ) from 1990-2002 showed a wellknown "status" considering epidemiological and clinical perspectives as well as therapeutic response to antimony (Sb) and amphotericin B.

Key words: epidemiology; leishmaniasis; leishmaniasis, cutaneous.

Recebido em 05.09.2003. / Received on September 09, 2003.

Aprovado pelo Conselho Consultivo e aceito para publicação em 12.03.2004. / Approved by the Consultive Council and accepted for publication on March 12, 2004.

* Trabalho realizado nos Serviços de Dermatologia e Anatomia Patológica do Hospital Universitário Clementino Fraga Filho. / Work done at the Services of Dermatology and Pathological

Anatomy, University Hospital Clementino Fraga Filho.

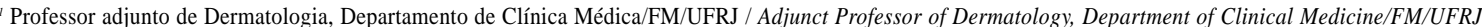

${ }^{2}$ Curso de Pós-Graduação em Dermatologia/FM/UFRJ / Postgraduate Student of Dermatology/FM/UFRJ.

${ }^{3}$ Professor adjunto de Patologia, Departamento de Patologia/FM/UFRJ / Adjunct Professor of Pathology, Pathology Department/FM/UFRJ.

${ }^{4}$ Estatístico da Comissão de Investigação Científica/HUCFF/ UFRJ / Statistician of the Scientific Investigation Commission /HUCFF/ UFRJ. 


\section{INTRODUÇÃO}

Leishmaniose tegumentar americana ou cutâneomucosa é doença causada por protozoários do gênero Leishmania e caracterizada por curso prolongado e lesões de pele, cartilagem e mucosa do trato respiratório superior. No Brasil, a doença apresenta dois padrões epidemiológicos:

a) surtos epidêmicos associados à derrubada das matas para construção de estradas, instalação de povoados, extração de madeira, agricultura e pecuária; ${ }^{1}$

b) leishmaniose não associada à derrubada das matas: processo migratório, ocupação de encostas, aglomerados na periferia de centros urbanos. Cães, eqüinos e roedores parecem ter papel importante como novos reservatórios do parasita, e tem-se discutido a possível adaptação de vetores e parasitas a ambientes modificados e a reservatórios. $^{1}$

A Leishmania Viannia braziliensis associada ao flebotomíneo Lutzomya intermedia é o agente/vetor mais freqüentemente encontrado no Estado do Rio de Janeiro (capital e interior). ${ }^{1} \mathrm{O}$ domicílio e os abrigos de animais domésticos dessas áreas endêmicas constituem o reduto principal desses vetores. No Rio de Janeiro, ocorre de modo semelhante em adultos e crianças de ambos os sexos, corroborando a idéia da importância da transmissão peridomiciliar. ${ }^{2}$

O período de incubação varia de duas ou três semanas até dois meses ou mais. As lesões surgem no local da picada do inseto e, portanto, localizam-se em áreas expostas.

A lesão inicial é pequena, eritematosa, consistente e elevada, e seu diâmetro aumenta gradualmente. Com freqüência ulcera, está recoberta por crosta, e nesse momento, os linfonodos são em geral palpáveis. A lesão ulcerada progride e atinge de três a $12 \mathrm{~cm}$ de diâmetro, com borda elevada bem característica, em moldura de quadro e base granulosa que sangra facilmente. É única ou múltipla, e a infecção secundária é comum. As que não ulceram também aumentam e tornam-se nodulares ou verrucosas. As lesões cutâneas tendem à cicatrização espontânea no prazo de até seis meses, exceto as de pavilhão auricular.

Comprometimento da mucosa ocorre na maioria das vezes por meio de disseminação sanguiínea ou linfática, exteriorizando-se três a 10 anos mais tarde após a resolução das lesões de pele. Às vezes, porém, não se identifica a porta de entrada, supondo-se que as lesões sejam originadas de infecção subclínica. ${ }^{\text {s }}$ Começa em geral na mucosa nasal, que se torna edematosa e ulcerada; há coriza e epistaxe. $\mathrm{O}$ septo cartilaginoso com feqüência está perfurado e, posteriormente, as asas do nariz ulceram, expondo estruturas subjacentes, com destruição da fossa nasal, mucosa e cartilagem. O comprometimento ósseo é infreqüente. Lábios, assoalho da boca, língua, faringe e amígdalas podem ser afetados e até mesmo a laringe, a traquéia e os brônquios. A mucosa, então, encontra-se espessada, edematosa, sangra facilmente, é dolorosa e tem odor fétido.

\section{INTRODUCTION}

American tegumentary or mucocutaneous leishmaniasis is a disease caused by protozoa of the genus Leishmania and characterized by prolonged course and lesions of the skin, cartilage and mucous membrane of the upper respiratory tract. In Brazil, the disease presents two epidemiological patterns:

a) epidemic outbreaks associated to clearing of the forests for construction of highways, installation of towns, wood extraction, agriculture and cattle ranching;

b) leishmaniasis not associated to clearing of the forests: migratory process, occupation of hillsides, agglomerates in the periphery of urban centers. Dogs, horses and rodents seem to play an important role as new reservoirs of the parasite, and it has been conjectured that the vectors and parasites have possibly adapted to the modified environments and to the construction of reservoirs. ${ }^{l}$

Leishmania Viannia braziliensis associated to the phlebotomine Lutzomya intermedia is the agent/vector most frequently found in the State of Rio de Janeiro (capital and hinterland). ${ }^{l}$ Dwellings and domestic animal shelters in these endemic areas constitute the main stronghold for the vectors. In Rio de Janeiro, it occurs with similar frequency among adults and children of both sexes, corroborating the importance of peridomiciliary transmission. ${ }^{2}$

The incubation period varies from two or three weeks to two months or more. The lesions appear at the site of the insect bite and therefore are located in exposed areas.

The initial lesion is small, erythematous, solid and elevated, its diameter increases gradually. Frequently it ulcerates and then is covered again by crust, and at that moment, the lymph nodes are usually palpable. The ulcerated lesion develops and reaches a diameter of three to 12 $\mathrm{cm}$, with very characteristic raised border, as in a picture frame and a granular base that bleeds easily. They can be single or multiple and secondary infection is common. Those that do not ulcerate also increase in size and become nodular or verrucous. The cutaneous lesions tend towards spontaneous cicatrization within up to six months, except those of the auricula.

Involvement of the mucous membrane occurs in most of the cases through blood or lymphatic dissemination, becoming evident three to 10 years after resolution of the skin lesions. Sometimes, however, the entry site can not be identified, and it is supposed that the lesions originate from a sub clinical infection. ${ }^{.}$In general, they begin in the nasal mucous membrane, then become edematous and ulcerated; coryza and epistaxis are present. The cartilaginous septum is frequently perforated and later, the wings of the nose ulcerate, exposing underlying structures, with destruction of the nasal fossa, mucous membrane and cartilage. Bone involvement is not frequent. The lips, floor of the mouth, tongue, pharynx and tonsils can be affected and even the larynx, windpipe and bronchi. The mucous membrane then becomes thickened, edematous, painful, bleeds easily and has a fetid odor. 
$\mathrm{O}$ presente trabalho avalia prospectivamente a casuística registrada no Hospital Universitário Clementino Fraga Filho/UFRJ, no período de 1990 a 2002.

\section{MATERIAL E MÉTODOS}

Quarenta e oito casos de leishmaniose tegumentar americana foram submetidos à anamnese, ao exame físico completo e aos seguintes exames complementares.

1) Hemograma completo, bioquímica do sangue, provas de função hepática, amilase, lipase, sedimento urinário, parasitológico de fezes, radiografia de campos pleuropulmonares, eletrocardiograma e exame otorrinolaringológico.

2) Intradermorreação de Montenegro: foi utilizado antígeno de Leishmania na concentração de $40 \mu \mathrm{g}$ de nitrogênio protéico/ml, padronizado por Melo et al.; ${ }^{3}$ foi injetado por via intradérmica o volume de $0,1 \mathrm{ml}$ de antígeno na face anterior do antebraço. Após 48 horas foi feita a leitura da área de enduração com auxílio de régua milimetrada. Foram considerados positivos os testes cujo diâmetro era igual ou superior a $5 \mathrm{~mm}$.

3) As biópsias foram realizadas com punch ou bisturi na pele e pinça saca-bocado no caso de mucosa, tendo sido utilizadas as colorações de hematoxilina-eosina e Giemsa. Nos casos de lesões mucosas e cutâneas concomitantes, a pele foi o local de eleição da biópsia.

4) Esquemas terapêuticos empregados.

A droga de escolha, o antimonial pentavalente $\mathrm{N}$-metil glucamina (Glucantime), é apresentada em ampola de $5 \mathrm{ml}$ contendo $1,5 \mathrm{~g}$ de $\mathrm{N}$-metil glucamina e $425 \mathrm{mg}$ de antimônio pentavalente $\left(\mathrm{Sb}^{\mathrm{v}}\right)$; a dose foi calculada para o máximo de $60 \mathrm{~kg}$ de peso. Os cuidados na administração foram verificação da pressão arterial antes das aplicações, paciente deitado e alimentado, compressas mornas no local da aplicação.

a. $\mathrm{Sb}^{\mathrm{v}}$ por via endovenosa diluído em soro glicosado (SG) a 5\% (dose máx: $15 \mathrm{ml} / \mathrm{dia}$ ) e aplicação lenta em duas horas.

- forma cutânea: $20 \mathrm{mg} / \mathrm{kg} / \mathrm{dia}$ por 30 dias

- forma cutânea com comorbidades (glomerulonefrite, hipertensão arterial, elevação da creatinina (>2mg), bilirrubinas (aumentadas 2X), TGO e TGP (aumentadas 2X), $\gamma \mathrm{Gt}$ (aumentada 3X), leucopenia $(<1.500$ granulócitos), alterações inespecíficas de repolarização ventricular, aumento do intervalo QT, fibrilação atrial crônica): $10 \mathrm{mg} / \mathrm{kg}$ em dias alternados durante 20 dias (10 doses)

forma mucosa (nasal, labial, palato): $20 \mathrm{mg} / \mathrm{kg} / \mathrm{dia}$ por 30 ou 90 dias

- forma mucosa de faringe/laringe: $15 \mathrm{mg} / \mathrm{kg}$ em dias alternados durante uma semana e, a seguir, $20 \mathrm{mg} / \mathrm{kg} /$ dia até alcançar 90 doses

b. Anfotericina B diluída em 500ml de SG a 5\%; acrescentados $100 \mathrm{mg}$ de hidrocortisona e $1.000 \mathrm{U}$ de heparina ao frasco. Infusão lenta em seis horas; meia hora antes da aplicação, 500mg de AAS e $25 \mathrm{mg}$ de prometazina/VO.

dose: $0,5 \mathrm{mg} / \mathrm{kg} /$ dose (máx: $50 \mathrm{mg}$ ) em dias alternados.
The present work is a prospective evaluation of the patients attended at the Clementino Fraga Filho Teaching Hospital /UFRJ, from 1990 to 2002.

\section{PATIENTS AND METHODS}

Forty eight cases of American tegumentary leishmaniasis were submitted to anamnesis, complete physical exam and the following complementary exams:

1) Complete blood count, blood biochemistry, tests of liver function, amylase, lipase, urinary sediment, parasitological exam of feces, $x$-ray of pleuropulmonary fields, electrocardiogram and otorhinolaryngologic exam.

2) Montenegro test: Antigen of Leishmania was used at a concentration of $40 \mu \mathrm{g}$ of proteic nitrogen $/ \mathrm{ml}$, standardized by Melo et al.,; $0.1 \mathrm{ml}$ of antigen was intradermally injected in the anterior face of the forearm. After 48 hours, the hardened are was measured using a millimetric ruler. Tests were considered positive when the diameter was $\geq 5 \mathrm{~mm}$.

3) The biopsies were performed with a punch or bistoury in the skin and biopsy tweezers in the case of the mucous membrane, the specimens were stained with hematoxylin and eosin and Giemsa. In the cases of simultaneous mucous and cutaneous lesions, the skin was selected for biopsy.

4) Therapeutic regimens. The drug of choice was antimonial pentavalent $\mathrm{N}$-methylglucamine (Glucantime), available in a $5 \mathrm{ml}$ flask containing $1.5 \mathrm{~g}$ of $\mathrm{N}$-methylglucamine and $425 \mathrm{mg}$ of pentavalent antimony $\left(S b^{v}\right)$; the dosage was calculated for a maximum weight of $60 \mathrm{~kg}$. Care in the administration included verification of the blood pressure before application, patient lying down and fed with lukewarm compresses on the application site.

$S b^{v}$ by endovenous path diluted in glucose 5\% ( $\max$ dose: $15 \mathrm{ml} /$ day) and slow application over two hours.

cutaneous form: $20 \mathrm{mg} / \mathrm{kg} /$ day for 30 days

cutaneous form with comorbidity (glomerulonephritis, arterial hypertension, elevation of the creatinine (>2 mg), bilirubin (increased 2X), TGO and TGP (increased 2X), $\gamma G t$ (increased 3X), leukopenia $(<1,500$ granulocytes), nonspecific alterations of ventricular repolarization, increase in the $Q T$ interval, chronic atrial fibrillation): $10 \mathrm{mg} / \mathrm{kg}$ on alternate days for 20 days (10 doses)

-mucous forms (nasal, labial, palate): 20 $\mathrm{mg} / \mathrm{kg} /$ day for 30 or 90 days

-laryngopharynx mucous forms: $15 \mathrm{mg} / \mathrm{kg}$ on alternate days for one week followed by $20 \mathrm{mg} / \mathrm{kg} /$ day until reaching 90 doses

b. Amphotericin B diluted in $500 \mathrm{ml}$ of glucose $5 \%$; added to $100 \mathrm{mg}$ of hydrocortisone and 1,000 U of heparin in the flask. Slow infusion over six hours; half hour before the application, $500 \mathrm{mg}$ of ASA and $25 \mathrm{mg}$ of promethazine, orally.

dose: $0.5 \mathrm{mg} / \mathrm{kg} /$ dose (max: $50 \mathrm{mg}$ ) on alternate days 
dose total de tratamento: 30 a $50 \mathrm{mg} / \mathrm{kg}$.

Indicações ${ }^{1}$

-persistência de lesões em atividade após 12 semanas do término de dois cursos completos de $\mathrm{Sb}^{\mathrm{v}}$;

- recidiva da doença (reaparecimento da lesão no período de um ano após a cura clínica);

- contra-indicação de $\mathrm{Sb}^{\mathrm{v}}$.

c. Semanalmente, durante o tratamento, foram realizados eletrocardiograma, hemograma, transaminases, contagem de plaquetas, tempo de atividade de protrombina, sódio, potássio, amilase, lipase, uréia, creatinina.

d. Parâmetros para avaliar cura clínica: regressão total da lesão cutânea no fim do tratamento ou até três meses após seu término, com exame otorrinolaringológico para avaliação de: desaparecimento da sintomatologia, regressão da hiperemia, ausência de crostas e desinfiltração. ${ }^{1}$

5) A análise estatística foi realizada pelos seguintes testes: para comparação entre proporções foi utilizado o teste de Qui-quadrado $(\chi 2)$ ou o teste exato de Fisher quando o teste de Qui-quadrado não pôde ser avaliado. O nível de significância adotado foi o de 5\%.

\section{RESULTADOS}

Vinte e oito casos do sexo masculino e 20 do sexo feminino, na faixa etária de 10 a 89 anos e exercendo as mais diversas atividades profissionais (apenas sete lavradores/14,58\%), constituem essa amostra (Tabela 1). Agrupando-se as faixas de 10 a 29, 30 a 49, 50 a 69 e acima de 70 anos, observou-se que não existe diferença significativa na distribuição etária entre os sexos $(p=0,33)$. Em 38 casos $(79,1 \%)$, a área provável de aquisição da doença foi o Rio de Janeiro. As úlceras predominaram nos membros inferiores (29 casos/48 pacientes) e nos membros superiores (20 casos/48 pacientes). Oito pacientes dos 48 estudados, apresentaram lesões mucosas com predomínio da mucosa nasal (16 casos/oito pacientes) (Tabela 2). Trinta e total dose of treatment: 30 to $50 \mathrm{mg} / \mathrm{kg}$.

\section{Indications}

- Persistence of active lesions 12 weeks after the end of two complete courses of $\mathrm{Sb}^{v}$;

- Recurrence of the disease (reappearance of the lesion within one year after clinical cure);

- Contraindication to $\mathrm{Sb}^{v}$.

c. Weekly, throughout treatment: Electrocardiogram, blood count, transaminases, platelets count, prothrombin time, sodium, potassium, amylase, lipase, urea, creatinine.

d. Evaluation parameters of clinical cure: Total regression of the cutaneous lesion by the end of the treatment or three months after, with otorhinolaryngologic exam for evaluation of disappearance of the symptoms, regression of the hyperemia, absence of crusts and disinfiltration.

5) Statistical analysis was performed using the following tests: Chi-square ( $\chi 2)$ for comparison of proportions or Fisher's exact test when the Chi-square test could not be evaluated. The 5\% level of significance was adopted.

\section{RESULTS}

The sample comprised twenty-eight male cases and 20 female cases, in the age group from 10 to 89 years and exercising the most varied professional activities (only seven farm workers $14.58 \%$ ) (Table 1). After grouping into age bands of 10 to 29, 30 to 49, 50 to 69 and over 70 years old, it was observed that there was no significant difference in the age distribution between sexes ( $p=0.33$ ). In $38(79.1 \%)$ cases, the disease was probably acquired in the Rio de Janeiro region. Ulcers prevailed in the lower limbs (29 cases 148 patients) and in the upper limbs (20 cases/48 patients). Mucous lesions were present in $8 / 48$ patients, with a prevalence in the nasal mucous membrane (16 cases/8 patients) (Table 2). Thirty two patients (66.6\%) referred to a disease duration of up to six

Tabela 1: Distribuição dos casos segundo idade e sexo Table 1: Distribution of the cases according to age and sex

\begin{tabular}{lllcc}
\hline Faixa Etária (Anos) / Age Range (Years) & \multicolumn{3}{c}{ Sexo Masculino / Male Sexo Feminino / Female } \\
\hline & $\mathrm{N}$ & $\%$ & $\mathrm{~N}$. & $\%$ \\
\cline { 2 - 5 } $10-19$ & 8 & 28.58 & 4 & 20 \\
$20-29$ & 5 & 17.86 & 2 & 10 \\
$30-39$ & 1 & 3.57 & 3 & 15 \\
$40-49$ & 4 & 14.29 & 5 & 25 \\
$50-59$ & 3 & 10.71 & 2 & 10 \\
$60-69$ & 2 & 7.14 & 2 & 10 \\
$70-79$ & 2 & 7.14 & 2 & 10 \\
$80-89$ & 3 & 10.71 & - & - \\
\hline Total & & 100.0 & 20 & 100.0 \\
\hline
\end{tabular}

Fonte: HUCFF-UFRJ (1990-2002) / Source: HUCFF/URFRJ (1990-2002)

$p=0.33$ 
Tabela 2: Distribuição segundo tipo e localização das lesões em 48 pacientes. / Table 2: Distribution according to type and localization of the lesions in 48 patients

\begin{tabular}{|c|c|c|c|c|c|c|c|c|c|}
\hline \multirow[b]{2}{*}{$\begin{array}{l}\text { Tipo } \\
\text { Type }\end{array}$} & \multirow[b]{2}{*}{$\begin{array}{l}\text { Cabeça } \\
\text { Head }\end{array}$} & \multicolumn{7}{|c|}{ Localização / Localization } & \multirow[b]{2}{*}{ Total } \\
\hline & & $\begin{array}{l}\text { Tronco } \\
\text { Trunk }\end{array}$ & $\begin{array}{l}\text { Abdome } \\
\text { Abdomen }\end{array}$ & $\begin{array}{l}\text { Genitália } \\
\text { Genitalia }\end{array}$ & $\begin{array}{l}\text { Mmss } \\
\text { Arms }\end{array}$ & $\begin{array}{l}\text { Mmii } \\
\text { Legs }\end{array}$ & $\begin{array}{l}\text { Nasal } \\
\text { Nasal }\end{array}$ & $\begin{array}{l}\text { Orofaringe } \\
\text { Laringe } \\
\text { Oro-pharynx- } \\
\text { larynx }\end{array}$ & \\
\hline Úlcera / Ulcera & 8 & 6 & 1 & - & 20 & 29 & 3 & 3 & 70 \\
\hline $\begin{array}{l}\text { Eritemato infiltrada } \\
\text { Infiltrated erythematous }\end{array}$ & 4 & & & & 3 & & 7 & 4 & 18 \\
\hline Crostosa / Crusted & 1 & & & 1 & 1 & 6 & & & 9 \\
\hline Cicatriz / Scar & 1 & & & & 2 & 5 & & & 8 \\
\hline $\begin{array}{l}\text { Perfuração ou destruição } \\
\text { Perforation or destruction }\end{array}$ & & & & & & & 6 & & 6 \\
\hline $\begin{array}{l}\text { Linfangite ascendente } \\
\text { Ascending lymphangitis }\end{array}$ & & & & & 5 & 1 & & & 6 \\
\hline Nódulo / Nodule & & & & & & 1 & & & 1 \\
\hline $\begin{array}{l}\text { Úlcero-verrucosa } \\
\text { Verrucous ulcer }\end{array}$ & & & 1 & & & & & & 1 \\
\hline Total & 14 & 6 & 1 & 1 & 31 & 42 & 16 & 7 & 119 \\
\hline
\end{tabular}

Fonte: HUCFF-UFRJ (1990-2002) / Source: HUCFF/UFRJ (1990-2002)

dois pacientes $(66,6 \%)$ referiram tempo de evolução até seis meses; 41 casos $(85,4 \%)$ tiveram teste de Montenegro positivo, sendo $20(41,6 \%)$ com enduração entre cinco e $10 \mathrm{~mm}$; dos sete casos com Montenegro negativo, seis referiram tempo de evolução até seis meses (Tabela 3). Observou-se que o tempo de evolução da doença não influenciou a resposta ao teste de Montenegro $(p=0,37)$.

Ao quadro histopatológico de reação inflamatória granulomatosa com células linfóides, histiocitárias e epitelióides, associaram-se em alguns casos as células gigantes multinucleadas e eosinófilos. Formas amastigotas foram encontradas em 17 casos $(35,4 \%)$ (Tabela 4). Pelo teste de Kappa, não se observou concordância significativa entre teste de Montenegro e exame histopatológico, ou seja, a discordância é estatisticamente relevante entre as duas técnicas diagnósticas $(\mathrm{k}=0,33, \mathrm{p}=0,90, \mathrm{n}=48)$.

Trinta e oito casos cutâneos foram tratados com $\mathrm{Sb}^{\mathrm{v}}$ e tiveram remissão clínica, sendo que um caso desenvolveu episódio único de urticária com angioedema; o esquema foi mantido sendo administradas, previamente ao Glucantime, hidrocortisona (100mg em infusão) e prometazina (25mg/VO); em três pacientes associaram-se comorbidades. months; 41 cases $(85.4 \%)$ presented a positive Montenegro test, of which $20(41.6 \%)$ presented induration between five and $10 \mathrm{~mm}$; of the seven cases with negative Montenegro test, six referred to a disease duration of up to six months (Table 3). It was observed that the disease duration did not influence the response to Montenegro test ( $p=0.37$ ).

The histopathological picture of granulomatous inflammatory reaction with lymphoid, histiocyte and epithelioid cells, was associated in some cases to multinucleated giant cells and eosinophils. Amastigote forms were found in 17 cases (35.4\%) (Table 4). According to the Kappa test, no significant agreement was observed between Montenegro test and histopathological exam, or in other words, the disagreement between the two diagnostic techniques was statistically significant ( $k=0.33, p=0.90, n=48)$.

Thirty eight cutaneous cases were treated with $\mathrm{Sb}^{v}$ and there was clinical remission, although one case developed a single episode of urticaria with angioedema; the outline was maintained with prior administration of Glucantime, hydrocortisone (100 $\mathrm{mg}$ by infusion) and promethazine (25 $\mathrm{mg}$, orally); three patients presented associated comorbidities. 
Tabela 3: Distribuição dos casos segundo tempo de evolução e teste de Montenegro. / Table 3: Distribution of the cases according to disease duration and Montenegro test

\begin{tabular}{|c|c|c|c|c|c|}
\hline \multirow[t]{2}{*}{ Tempo de Evolução / Disease duration } & \multicolumn{4}{|c|}{ Teste de Montenegro / Montenegro Test } & \multirow[t]{2}{*}{ Total } \\
\hline & NEG & $5-10 \mathrm{~mm}$ & $11-20 \mathrm{~mm}$ & $>20 \mathrm{~mm}$ & \\
\hline $0-6$ meses / months & 6 & 15 & 7 & 4 & $32(66.67 \%)$ \\
\hline$>6 \mathrm{~m}-1 \mathrm{ano} /$ year & 1 & 2 & 1 & - & $4(8.33 \%)$ \\
\hline$>1$ ano / year & - & 3 & 3 & 2 & $8(16.67 \%)$ \\
\hline Indeterminado / Indeterminate & - & - & 3 & 1 & $4(8.33 \%)$ \\
\hline Total & $7(14.58 \%)$ & $20(41.67 \%)$ & $14(29.17 \%)$ & $7(14.58 \%)$ & $48(100.0 \%)$ \\
\hline
\end{tabular}

Fonte: HUCFF-UFRJ (1990-2002) / Source: HUCFF/URFRJ (1990-2002)

$p=0.37$

Em um caso de forma mucosa (perfuração do septo e crostas aderidas), 30 doses levaram à remissão; em um caso de forma mucosa (granulação grosseira do palato), 30 doses foram suficientes para induzir à remissão. Dois pacientes de forma mucosa (vegetação em lábio inferior, ulceração de palato, edema e eritema do nariz e destruição do septo) cumpriram o esquema por 90 dias com remissão clínica; em um caso mucoso (aumento de volume do nariz, destruição do septo, epiglote edemaciada com superfície irregular e rouquidão) o esquema foi inicialmente progressivo, alcançando 90 doses, com regressão clínica.

Um paciente com síndrome de Down e lesões exulcerocrostosas em tronco e membros evoluiu com infecção urinária, choque séptico e óbito na décima dose de Glucantime (20mg Sb $/ \mathrm{kg} / \mathrm{dia})$.

Em quatro casos foi empregada a anfotericina B: um paciente há dois anos já havia sido tratado com 60 injeções de Glucantime, e o septo nasal apresentava aspecto granuloso; um paciente com destruição do septo, tratado inicialmente com Glucantime por 30 dias, apresentou recidiva um ano após; em outro paciente, um ano após 22 doses de $\mathrm{Sb}^{\mathrm{v}}$, havia lesões papulonodulares em base infiltrada na região frontal, malar, mentoniana e exulcerações de lábio inferior com pontos hemorrágicos, e, na oitava dose de $\mathrm{Sb}^{\mathrm{v}}$, apresentou-se leucopenia (1366); um paciente com forma cutânea por ter desenvolvido reação pirogênica ao Glucantime. Todos os tratados com anfotericina B tiveram regressão clínica das lesões.
In one case of the mucous form (perforation of the septum and adhered crusts), 30 doses achieved remission; in one case of the mucous form (crude granulation of the palate), 30 doses were sufficient to induce remission. Two patients with the mucous form (vegetation in inferior lip, ulcerated palate, edema and erythema of the nose and destruction of the septum) followed the regimen for 90 days with clinical remission; in one mисоus case (increased volume of the nose, destruction of the septum, edematous epiglottis with irregular surface and hoarseness) the outline was initially progressive, reaching 90 doses, with clinical regression.

A patient with Down's syndrome and crusted erosions lesions in the trunk and legs and arms coursed with urinary infection, septic shock and died after the tenth dose of Glucantime (20 $\mathrm{mg} \mathrm{Sb}^{\mathrm{r}} / \mathrm{kg} /$ day).

In four cases amphotericin $B$ was used: One patient had been treated two years previously with 60 injections of Glucantime, and the nasal septum presented a granular aspect; one patient with destruction of the septum and treated initially with Glucantime for 30 days, presented recurrence one year after; another patient, one year after 22 doses of $S b^{v}$, presented papulonodular lesions in base infiltrated in the frontal, malar, chin area (mentum) and ulceration of the lower lip with hemorrhagic points, and, at the eighth dose of $S b^{v}$, the patient developed leukopenia (1366); one patient with cutaneous form after developing pyrogenic reaction to Glucantime. All patients treated with amphotericin B presented clinical regression of the lesions.

Tabela 4: Distribuição dos casos segundo teste de Montenegro e achado de amastigotas no exame histopatológico. / Table 4: Distribution of the cases according to Montenegro test and finding of amastigotes in the histopathological exam

\begin{tabular}{lcc}
\hline Exames / Exams & $\begin{array}{c}\mathrm{N}^{\mathrm{o}} \text { de Exames Realizados } \\
\text { Number of Exams Carried Out }\end{array}$ & Positivos / Positive \\
\hline & 48 & $41(85.41 \%)$ \\
Teste de Montenegro / Montenegro test & 48 & $17(35.4 \%)$ \\
Exame histopatológico / Histopathological exam & & \\
\hline
\end{tabular}

Fonte: HUCFF-UFRJ (1990-2002) / Source: HUCFF/URFRJ (1990-2002) 


\section{DISCUSSÃO}

O diagnóstico da doença nesta casuística foi baseado nos critérios clínicos e epidemiológicos, positividade da reação de Montenegro, detecção do parasita nas lesões e alterações histopatológicas sugestivas. A distribuição etária homogênea entre os sexos e a atividade profissional variada refletem o perfil da doença no estado ${ }^{2}$ (Tabela 1). A leishmaniose tegumentar está presente desde o início do século passado (1915) no Estado do Rio de Janeiro. As áreas de provável aquisição da doença em $79,1 \%$ dos casos foram a Zona Oeste, Baixada Fluminense e Grande Rio.

A lesão ulcerada nos membros inferiores foi o achado mais freqüente, compatível com os dados da literatura geral; ${ }^{4-6}$ foram observados seis casos de linfangite ascendente (Tabela 2). Linfangite e adenomegalia são consideradas próprias da doença até 90 dias e características da subespécie Leishmania braziliensis guyanensis. ${ }^{1}$ No entanto, esses achados podem ser verificados em outras espécies. Essas duas manifestações impõem o diagnóstico diferencial de esporotricose; nessa micose subcutânea, a linfangite evolui com nodulação. A mucosa mais comprometida foi a nasal, confirmando observações anteriores ${ }^{4-6}$ (Tabela 2). As manifestações mucosas incluíram infiltração e eritema do nariz com perfuração do septo nasal anterior; perfuração acompanhada de crostas aderidas e aspecto granuloso; obstrução nasal bilateral, rinorréia e prurido como manifestações vinculadas; edema de epiglote com rouquidão, palatos duro e mole com hiperemia e granulação grosseira, úlcera de palato mole e vegetação de lábio inferior.

O teste de Montenegro, de hipersensibilidade tardia, é positivo em $90 \%$ dos indivíduos com doença ativa ou pregressa; ${ }^{1}$ torna-se positivo a partir do terceiro mês de infecção, assim permanecendo pelo resto da vida. Pode apresentar-se negativo nos seguintes casos: na forma disseminada e cutâneo-difusa, na leishmaniose visceral e em pacientes imunodeprimidos. Nas lesões mucosas, a resposta ao teste é mais intensa (ulceração e necrose local). Nesta amostra, 85,4\% dos casos foram positivos, com leitura de cinco a 10mm em $20(41,6 \%)$ dos casos (Tabela 3). Nenhum dos pacientes negativos - que predominaram no tempo de evolução até seis meses - apresentava comorbidades (Tabela 3).

As alterações histopatológicas variam em função do tempo de evolução da doença e do aspecto clínico das lesões. ${ }^{1}$ Nesta amostra prevaleceu o processo inflamatório crônico granulomatoso. À medida que o processo granulomatoso se organiza, diminui o número de parasitas, sendo difícil seu achado em lesões antigas. No entanto, a identificação de parasitas é fundamental para o diagnóstico histopatológico. O percentual de exames positivos é variável segundo os autores $(25,4 \%, 63,7 \%, 18,8 \%, 47 \%)^{4,6,9-11} \mathrm{e}$ neste trabalho ocorreu em 35,4\% dos casos (Tabela 4).

Nos casos de lesões de laringe e faringe podem ocorrer edema e insuficiência respiratória aguda; é recomendável iniciar o tratamento com dose menor. Foi a conduta

\section{DISCUSSION}

Diagnosis of the disease in this sample of patients was based on clinical and epidemiological criteria, positive Montenegro test, detection of the parasite in lesions and suggestive histopathological alterations. The homogeneous age distribution between genders and varied professional activities reflects the profile of the disease in the State ${ }^{2}$ (Table 1). Tegumentary leishmaniasis has been present in Rio de Janeiro State since the beginning of the last century (1915). The areas of probable acquisition of the disease in $79.1 \%$ of cases were the metropolitan west side, Baixada Fluminense and Great Rio.

Ulcerated lesions in the lower limbs were the most frequent finding, corroborating data in the general literature ; $^{4-6}$ six cases were observed of ascending lymphangitis (Table 2). Lymphangitis and adenomegaly are considered part of the disease at 90 days and characteristics of the subspecies Leishmania braziliensis guyanensis. ${ }^{1}$ However, these findings can be verified in other species. Both these manifestations demand a differential diagnosis with sporotrichosis, a subcutaneous mycosis in which the lymphangitis develops with nodulation. The nasal mucous membrane was the most involved, confirming previous observations ${ }^{4-6}$ (Table 2). Mucous manifestations included infiltration and erythema of the nose with perforation of the anterior nasal septum; accompanied by perforation of adherent crusts and granular aspect; bilateral nasal obstruction, rhinorrhea and pruritus as associated manifestations; edematous epiglottis with hoarseness, hard and soft palates and with hyperemia and coarse granulation, ulcer of the soft palate and vegetation of lower lip.

Montenegro test with late hypersensitivity is positive in $90 \%$ of the individuals with active or previous disease, ${ }^{.1}$ it becomes positive as of the third month of infection, remaining positive for the rest of the life. It can become negative in the following cases: in the disseminated and cutaneous-diffuse forms, in visceral leishmaniasis and in immunodeficient patients. In the mucous lesions, the response to the test is more intense (ulceration and local necrosis). In this sample, $85.4 \%$ of the cases were positive, with readings from five to $10 \mathrm{~mm}$ in 20 (41.6\%) of the cases (Table 3). None of the negative patients presented comorbidities and the predominant disease duration was up to six months (Table 3).

The histopathological alterations vary according to the disease duration and clinical aspect of the lesions. ${ }^{I}$ In this sample the chronic granulomatous process prevailed. As the granulomatous process becomes organized, the number of parasites decreases, such that they are rarely found in old lesions. However, identification of the parasites is fundamental for histopathological diagnosis. The percentage of positive exams varies according to the authors $(25.4 \%, 63.7 \%, 18.8 \% \text { and } 47 \%)^{4,6,-11}$ and in this work it occurred in $35.4 \%$ of the cases (Table 4 ).

Edema and acute respiratory insufficiency can occur in cases involving lesions of the larynx and pharynx; it is advisable to begin the treatment with a smaller dosage. This was the 
seguida no caso de lesão de epiglote.

Os casos de lesão mucosa nasal foram radiografados de rotina (seios da face) para avaliação de rinite purulenta e sinusite. Em um caso com perfuração do septo nasal, obstrução bilateral e secreção purulenta, foi instituída ampicilina $(50 \mathrm{mg} / \mathrm{kg} / \mathrm{dia} / \mathrm{VO})$ por três semanas.

Os efeitos colaterais observados com antimonial pentavalente foram artralgia, mialgia, epigastralgia, cefaléia, constipação, anorexia, febre, rash, angioedema, elevação da uréia, creatinina, transaminases, amilase e lipase, leucopenia, eosinofilia, alterações eletrocardiográficas (alterações inespecíficas da repolarização ventricular, extrassistolia ventricular e prolongamento do segmento QT). O caso de angioedema em forma cutânea exclusiva, em episódio único, foi contornado com corticóide e antihistamínico, à semelhança do esquema com anfotericina B.

Oliveira Neto e colaboradores, ${ }^{7.8}$ no Rio de Janeiro, trataram a forma cutânea com $\mathrm{Sb}^{\mathrm{v}}$ na dose de 3,8 a $8,8 \mathrm{mg} / \mathrm{kg} / \mathrm{dia} / \mathrm{IM}$ por 30 dias; após cinco anos, as lesões permaneciam cicatrizadas, e não havia comprometimento mucoso. A utilização de doses abaixo daquelas recomendadas pela OMS/MS em pacientes com comorbidades pareceu ao autor alternativa segura na forma cutânea.

Os efeitos colaterais da anfotericina B são de dois tipos: imediatos, como febre, calafrios, náuseas e vômitos, que podem ser evitados com ácido acetilsalicílico e anti-histamínico; e tardios por efeito cumulativo com elevação da uréia e creatinina, queda de potássio sérico e anemia. Decorrentes da infusão venosa da droga, as flebites podem ser evitadas com aplicação de calor local e administração de heparina e hidrocortisona no soro. São habitualmente recomendadas as primeiras aplicações com $0,25 \mathrm{mg} / \mathrm{kg}$ até obter-se boa tolerância, passando-se a $0,5 \mathrm{mg} / \mathrm{kg}$ e depois à dose de manutenção máxima $(1 \mathrm{mg} / \mathrm{kg})$. No entanto, a dose de $0,5 \mathrm{mg} / \mathrm{kg}$, apesar de alongar o tempo de tratamento, parece ao autore ser de mais simples manejo.

O paciente que evoluiu para óbito apresentava lesões cutâneas em número superior a 10, caracterizando a forma disseminada. Lesões múltiplas ou disseminadas associadas à infecção por Leishmania braziliensis têm sido descritas.? Nesses casos, são polimorfas, freqüentemente associadas ao comprometimento mucoso, o Montenegro é positivo e há boa resposta terapêutica ao antimonial. ${ }^{13}$

Não se vinculou a evolução do caso para sepse e óbito à terapêutica antimonial. Infecção urinária é a mais freqüente fonte de infecção nosocomial. No entanto, sepse urinária, atualmente parece ser infreqüente em pacientes gravemente enfermos, exceto em situação de obstrução ou instrumentação de trato urinário. ${ }^{14}$

A freqüência e gravidade dos efeitos colaterais guardam relação direta com as doses e duração do tratamento. Geralmente surgem ao final das duas semanas, quando há estabilização do nível sérico crescente. ${ }^{5} \mathrm{~A}$ urticária é considerada rara, mas pode ocorrer choque anafilático nas primeiras aplicações. ${ }^{5}$ conduct followed in the case of lesion of the epiglottis.

The cases of nasal mucous lesion were routinely $x$ rayed (paranasal sinuses) for evaluation of purulent rhinitis and sinusitis. In a case with perforation of the nasal septum, bilateral obstruction and purulent secretion, ampicillin was initiated (50 mg/kg/day/via oral) for three weeks.

The side effects observed with pentavalent antimonial were arthralgia, myalgia, epigastralgia, migraine, constipation, anorexia, fever, rash, angioedema, elevation of urea, creatinine, transaminases, amylase and lipase, leukopenia, eosinophilia, electrocardiographic alterations (nonspecific alterations of the ventricular repolarization, ventricular extrasystole and prolongation of the segment $Q T$ ). The case of angioedema with exclusively cutaneous form and a single episode, was successfully treated with corticoid and antihistamine, using a regimen similar to that of amphotericin $B$.

Oliveira Neto and col. ${ }^{7.8}$ in Rio de Janeiro, treated the cutaneous form with $\mathrm{Sb}^{v}$ using an intramuscular dose of 3.8 to $8.8 \mathrm{mg} / \mathrm{kg} /$ day for 30 days; after five years, the lesions continued cicatrized and there was no mucous involvement. The use of doses below those recommended by the WHO/Health Ministry in patients with comorbidities appears to the author to be a safe alternative in the cutaneous form.

The side effects of amphotericin B are of two types: immediate, such as fever, chills, nausea and vomiting, that can be avoided with acetylsalicylic acid and antihistamine; and late by a cumulative effect with elevation of urea and creatinine, reduction in serum potassium and anemia. Phlebitis due to intravenous infusion of the drug can be avoided with application of local heat and administration of heparin and hydrocortisone in the serum. These are normally recommended for first applications with $0.25 \mathrm{mg} / \mathrm{kg}$ until a good tolerance is obtained, and is then increased $0.5 \mathrm{mg} / \mathrm{kg}$ and later to the maximum maintenance dose $(1 \mathrm{mg} / \mathrm{kg})$. Nevertheless, a dose of $0.5 \mathrm{mg} / \mathrm{kg}$, in spite of prolonging treatment time, seems to the author to be a more simple management.

The patient that died presented more than 10 cutaneous lesions, characterizing the disseminated form. Multiple or disseminated lesions associated to infection by Leishmania braziliensis have been described. ${ }^{7}$ These cases are polymorphic and frequently associated to mисои involvement, Montenegro test is positive and there is good therapeutic response to antimonial. ${ }^{13}$

The course of the case to sepsis and death was not associated with the antimonial therapeutics. Urinary infection is the most frequent source of nosocomial infection. However, urinary sepsis now seems to be infrequent in seriously sick patients, except in a situation of obstruction or instrumentation of the urinary tract. ${ }^{14}$

The frequency and severity of the side effects maintain a direct relationship with the number of doses and duration of the treatment. They usually appear at the end of two weeks, when there is stabilization of the increasing serum level. ${ }^{5}$ Urticaria is considered rare, but anaphylactic shock can occur in the first applications. ${ }^{5}$ 


\section{CONCLUSÕES}

A análise prospectiva de 48 casos registrados no Hospital Universitário Clementino Fraga Filho/UFRJ mostrou perfil das atividades profissionais corroborando a importância da transmissão peridomiciliar; maior freqüência das úlceras de membros inferiores e em mucosa nasal; sensibilidade do teste de Montenegro; e boa resposta ao antimonial e anfotericina B.

\section{REFERÊNCIAS / REFERENCES}

1. Manual de Controle da Leishmaniose tegumentar americana. Brasília: Ministério da Saúde. Fundação Nacional de Saúde Pública. 2000.

2. Sabroza PC. O domicílio como fator de risco na leishmaniose tegumentar americana. Estudo epidemiológico em Jacarepaguá, Município do Rio de Janeiro. Tese. Rio de Janeiro: Escola Nacional de Saúde Pública, 1981.

3. Melo MN, Mayrink W, Costa CA, Magalhães PA, Dias M, Williams P. Padronização do antígeno de Montenegro. Rev Inst Med Trop 1977; 19: 161-64.

4. Carvalho MLR, Hueb M, Fontes CJF, Guedes AM, Afonso LCC, Melo MN. Leishmaniose tegumentar no Estado de Mato Grosso (Brasil): estudo clínico, laboratorial e terapêutico. An bras Dermatol 2002; 77(1): 45-56.

5. Da Cruz AM, Azeredo-Coutinho RB. Leishmaniose tegumentar americana. In: Batista RS, Gomes AP, Igreja RP, Huggins DW, eds. Medicina Tropical. Abordagem atual das doenças infecciosas. Rio de Janeiro: Cultura Médica, 2000: 131-40.

6. Nogueira LSC, Sampaio RNR. Estudo hospitalar da leishmaniose tegumentar americana (LTA): epidemiologia e tratamento. An bras Dermatol 2001; 76(1): 51-62.

7. Oliveira-Neto MP. Leishmaniose tegumentar no Estado do Rio de Janeiro. Estudo de 648 casos observados no Hospital Evandro Chagas, Fundação Oswaldo Cruz. Tese. Rio de Janeiro: Instituto Oswaldo Cruz, Fundação Oswaldo Cruz, 1998.

8. Oliveira-Neto MP, Schubach A, Araújo ML, Pirmez C. High and low doses of antimony ( $\mathrm{SbV}$ ) in american cutaneous leishmaniasis. A five years follow-up study of 15 patients. Mem Inst Oswaldo Cruz 1996; 91 (2): 207-9.

9. Cuba CAC, Marsden PD, Barreto AC, Rocha R, Sampaio RR. Diagnóstico parasitológico e imunológico de leishmaniose tegu-

\section{CONCLUSIONS}

The prospective analysis of 48 cases registered at the Teaching Hospital Clementino Fraga Filho/UFRJ showed a profile of professional activities that corroborates the importance of peridomiciliary transmission; greater frequency of ulcers in the lower limbs and nasal mucous membrane; sensitivity of Montenegro test; and good response to antimonial and amphotericin $B$.

mentar americana. Bol Ofic Sanit Panam 1980; 89: 195-208.

10. Magalhães AA, Moraes MAP, Raick AN, Llanos-Cuentas A, Costa JML, Cuba CC, Marsden PD. Histopatologia da leishmaniose tegumentar por Leishmania braziliensis braziliensis. 1. Padrões histopatológicos e estudo evolutivo das lesões. Rev Inst Med Trop São Paulo 1986; 4: 253-62.

11. Hueb M. Leishmaniose tegumentar em Mato Grosso: aspectos do diagnóstico clínico e laboratorial de pacientes atendidos no Serviço de referência para leishmanioses do Hospital Júlio Müller. Dissertação de Mestrado. Cuiabá: Universidade Federal do Mato Grosso, 1977.

12. Wanke NCF, Birkenhauer MC, Maceira JMP, Silva FC, Perez M. Leishmaniose tegumentar. Estudo retrospectivo de 65 casos. An bras Dermatol 1991; 66(2): 49-54.

13. Carvalho EM, Barcal A, Costa JML, Bittencourt A, Marsden P. Clinical and immunopathological aspects of disseminated cutaneous leishmaniasis. Acta Tropica 1994; 56: 315-25.

14. Rocco JR. Sepse. In: Schechter M, Marangoni DV, eds. Doenças Infecciosas: conduta diagnóstica e terapêutica. Rio de Janeiro: Guanabara Koogan, 1998: 121-45.

ENDEREÇO PARA CORRESPONDÊNCIA: / MAILING ADDRESS:
Nurimar Concei ção Fernandes
Rua Alexandre de Gusmão, 28 / 201 - Tijuca
$20520-120$ Rio de Janeiro RJ
Tel: (21) $2568-4158$

